\title{
GROUP -B STREPTOCOCCAL GENITAL INFECTION AND PREMATURE RUPTURE OF MEMBRANES
}

\author{
By \\ Mahmoud Abd El-Wehab Hamed Ghoneim ${ }^{1}$, Fahd Abd El-Eal Al- \\ Omda $^{1}$, Ahmed Taha Abd El-Fattah ${ }^{1}$ and Mohamed Abd El-Hameed \\ Khedr $^{2}$ \\ Departments of ${ }^{1}$ Obstetrics \& Gynecology and ${ }^{2}$ Clinical Pathology - Faculty of Medicine, \\ Al-Azhar University
}

Corresponding author: Mahmoud Abd El-Wehab Hamed Ghoneim,

Mobile: (+20) 01003650427, E-mail: m-abdelwehab@yahoo.com

\begin{abstract}
Background: Premature rupture of membranes (PROM) is an obstetric condition that involves spontaneous amniotic fluid leakage at least one hour before onset of labor complicates 5-10\% of all deliveries. Its etiology is multi-factorial as polyhydramnios, cervical incompetence, congenital uterine abnormality, trauma and previous cervical biopsy.

Objective: To assess the effect of vaginal colonization with group B streptococcal infection on the incidence of premature rupture of membranes and how to prevent its complications in pregnant women.

Patients and methods: This was a prospective study included the period between December 2018 till May 2020 and was conducted on one hundred and forty (140) pregnant women suffered from vaginal infection with group B streptococcal infection selected from the antenatal Care Clinic of the Obstetrics and Gynecology Department of Al-Azhar University Hospitals and Sedi Salem General Hospital. Pregnant women with single viable fetus, gestational age after 28 weeks, and those with no past history of premature rupture of membranes were included in this study. Those with polyhydramnious, UTI, dead fetus, Diabetes mellitus, congenital fetal malformation, multiple pregnancies and with fibroid disease were excluded from this study.
\end{abstract}

Results: The presence of vaginal infection increase the incidence of premature rupture of membranes, especially if those infections were due to streptococci group B, premature rupture of membranes increased.

Conclusion: The presence of vaginal infections increased the incidence of PROM more.

Keywords: Group B streptococcal infection, PROM, Pregnant women.

\section{INTRODUCTION}

The etiology of previable PPROM is multi-factorial. It is hypothesized that a weakness in the chorio-amniotic membrane occurs as a result of either membrane stretch or degradation of the extra-cellular matrix (Mohan et al., 2018).
The etiology of PROM is diverse. It includes polyhydramnios, cervical incompetence, uterine abnormality, trauma and previous cervical conization or cone biopsy. Other factors that have been implicated include past obstetric history of PROM, black race, smoking of cigarettes, poor nutrition and genital infections. 
Genital infections are implicated in morbidities among women of reproductive age group especially during the pregnancy period. Inflammatory cells produced by genital infections are implicated in weakening of the fetal membranes among pregnant women thus causing premature rupture of membranes (PROM). Genital infections have been found to be associated with PROM. Women with bacterial vaginosis (BV) were more likely to develop PROM compared with women without BV (Nakubulwa et al., 2015). The evidence that Group B streptococci (GBS) may be a cause of PROM was supported by the fact that GBS causes inflammatory responses in fetal membranes in experimental and epidemiological studies (Peltier et al., 2012).

Numerous risk factors for GBS vaginal colonization have been identified both biological and socioeconomic in nature. Biological factors include a history of PROM (Alp et al., 2016), gastrointestinal GBS colonization (LeDoare and Heath, 2013), and increased maternal age (Patras and Nizet, 2018).

Intrapartum antibiotic prophylaxis (IAP) is recommended for women with preterm pre-labor rupture of membranes, but not for women in preterm labor with intact amniotic membranes, nor for women with pre-labor rupture of membranes at term or near term (36 weeks gestation and above). The latter is based on evidence from studies including women with membrane rupture duration under $12 \mathrm{~h}$, and there may be a benefit from IAP in women with prolonged rupture of membranes (>18 h) (Kobayashi et al., 2016).
The aim of the study was to assess the effect of vaginal colonization with group B streptococcal infection on the incidence of premature rupture of membranes and how to prevent its complications in pregnant women.

\section{PATIENTS AND METHODS}

This was a prospective study included the period between December 2018 till May 2020 and was conducted on one hundred and forty (140) pregnant women with Premature Rupture of Membranes selected from the antenatal Clinic of the Obstetrics and Gynecology Department of Al-Azhar Main University Hospital and Sedi Salem General Hospital.

\section{Inclusion criteria:}

- Single viable fetus.

- Gestational age after 28 weeks.

- Premature rupture of membranes.

\section{Exclusion criteria:}

- Pregnancies with polyhydramnious.

- Pregnancies with UTI.

- Dead fetus.

- Diabetes mellitus.

- Congenital fetal malformation.

- Multiple pregnancies.

- Pregnancies with fibroid disease.

All patients were subjected to Complete medical history taking, clinical examinations and laboratory investigations (complete blood picture, urine analysis "for pus cells", cytological examination for vaginal discharge and culture of the vaginal discharge for detection of streptococcal infection and its type). 
Follow-up: All patients positive for group B streptococcal infection were followed for reaching the end time of delivery.

\section{Statistical analysis:}

Analysis of data was done using Statistical Program for Social Sciences version 22 (SPSS Inc., Chicago, IL,
USA). Quantitative variables were described in the form of mean and standard deviation. Qualitative variables were described as number and percent. Qualitative variables were compared using Chi-square (X2) test or Fisher's exact test when frequencies were below five. $\mathrm{P}$ value $<0.05$ is considered significant.

\section{RESULTS}

The age of cases ranged between 22-35 years with a mean age of $29.19 \pm 3.4$ years. The gestational age of the studied women ranged between $35-40$ week with a mean gestational age of $37.4 \pm 1.7$ weeks (Table 1).

Table (1): Demographic data of cases of the study

\begin{tabular}{|c|c|c|}
\hline Variable & Range & Mean \pm S.D \\
\hline Age (years) & $\mathbf{2 2 - 3 5}$ & $\mathbf{2 9 . 1 9} \pm 3.4$ \\
\hline Gestational Age (weeks) & $35-40$ & $37.4 \pm 1.7$ \\
\hline
\end{tabular}

One hundred and five cases of the study $(105 / 140,75 \%)$ had fever during presentation while 35 cases $(35 / 140,25 \%)$ didn't have fever, all cases of the study had lower abdominal pain (140/140, $100 \%)$, while 115 cases $(115 / 140,82.1 \%)$ had vaginal discharge and $25(25 / 140$, 17.9\%) (Table 2).

Table (2): Clinical data of cases of the study

\begin{tabular}{|c|c|c|c|c|c|}
\hline \multirow{2}{*}{ Data } & \multicolumn{2}{|c|}{ Yes } & \multicolumn{2}{|c|}{ No } & \multirow{2}{*}{ P value } \\
\cline { 2 - 5 } & No & $\%$ & No & \% & \\
\hline Fever & $\mathbf{1 0 5}$ & $\mathbf{7 5 \%}$ & $\mathbf{3 5}$ & $\mathbf{2 5 \%}$ & $\mathbf{0 . 0 1}^{*}$ \\
\hline Lower abdominal pain & $\mathbf{1 4 0}$ & $\mathbf{1 0 0 \%}$ & $\mathbf{0}$ & $\mathbf{0 . 0 \%}$ & $\mathbf{0 . 0 0 1}^{*}$ \\
\hline Vaginal discharge & $\mathbf{1 1 5}$ & $\mathbf{8 2 . 1}$ & $\mathbf{2 5}$ & $\mathbf{1 7 . 9}$ & $\mathbf{0 . 0 1}^{*}$ \\
\hline
\end{tabular}

During laboratory examination of cases all cases of the study had leukocytosis $(140 / 140,100 \%)$, also all cases of the study when subjected to urine analysis found pus cells of different rages
$(140 / 140,100 \%)$, while 115 cases $(115 / 140,82.1 \%)$ had positive vaginal smear for organisms and $25(25 / 140$, $17.9 \%$ ) of the vaginal smear didn't had organism in the vaginal smear (Table 3).

Table (3): Laboratory data of cases of the study

\begin{tabular}{|c|c|c|c|c|c|}
\hline \multirow{2}{*}{ Data } & \multicolumn{2}{|c|}{ Yes } & \multicolumn{2}{|c|}{ No } & \multirow{2}{*}{ P value } \\
\cline { 2 - 5 } Variables & No & $\%$ & No & \% & \\
\hline Leukocytosis & $\mathbf{1 4 0}$ & $\mathbf{1 0 0 \%}$ & $\mathbf{0}$ & $\mathbf{0 . 0 \%}$ & $\mathbf{0 . 0 0 1}^{*}$ \\
\hline Urine analysis for pus cells & $\mathbf{1 4 0}$ & $\mathbf{1 0 0 \%}$ & $\mathbf{0}$ & $\mathbf{0 . 0 \%}$ & $\mathbf{0 . 0 0 1}^{*}$ \\
\hline Vaginal smear & 115 & $\mathbf{8 2 . 1}$ & $\mathbf{2 5}$ & $\mathbf{1 7 . 9}$ & $\mathbf{0 . 0 1}^{*}$ \\
\hline
\end{tabular}


After culturing and incubation of the positive cases of vaginal smear $(115 / 140$, $82.1 \%)$ we found 30 cases (30/115, $26.1 \%$ ) had mixed organism in the culture, 65 cases $(65 / 115,56.5 \%)$ had streptococcus group B bacteria, 17 cases $(17 / 115,14.8 \%)$ had fungus in the culture while only three cases $(3 / 115,2.6 \%)$ had staphylococci in the culture (Table 4).

Table (4): Organisms in the culture and incubation of the vaginal smear of cases of the study

\begin{tabular}{|l|c|c|c|}
\hline Positive smear cases $(\mathbf{n}=\mathbf{1 1 5})$ & No & \% & P-value \\
\hline Mixed & $\mathbf{3 0}$ & $\mathbf{2 6 . 1 \%}$ & $\mathbf{0 . 0 3 3}^{*}$ \\
\hline Streptococcus group B & $\mathbf{6 5}$ & $\mathbf{5 6 . 5 \%}$ & $\mathbf{0 . 0 2 1}^{*}$ \\
\hline Fungus & $\mathbf{1 7}$ & $\mathbf{1 4 . 8 \%}$ & $\mathbf{0 . 2 2 2}$ \\
\hline Staphilococcus & $\mathbf{3}$ & $\mathbf{2 . 6 \%}$ & $\mathbf{0 . 7 3 8}$ \\
\hline
\end{tabular}

Twenty cases of our studied cases developed premature rupture of membranes $(20 / 140,14.3 \%)$ while the remaining ends their pregnancy with intact membranes (120/140, 85.7\%). Eighteen of cases of premature rupture of membranes had streptococcal group B infection $(18 / 65,27.7 \%)$ while only two cases of PMRM belonged to other infection $(2 / 55,3.6 \%)$ and the statistical analysis revealed that the presence of streptococcal vaginal infection predispose to PMRP $(\mathrm{P}=0.008)$ (Table 5).

Table (5): PMRM in cases of the study and its relation to type of infection in cases of the study

\begin{tabular}{|c|c|c|c|c|c|}
\hline \multirow{2}{*}{$\begin{array}{r}\text { Positive smear cases } \\
(n=115)\end{array}$} & \multicolumn{2}{|c|}{ Yes } & \multicolumn{2}{|c|}{ No } & \multirow{2}{*}{ P-value } \\
\hline & No & $\%$ & No & $\%$ & \\
\hline PMRM & 20 & $14.3 \%$ & 120 & $85.7 \%$ & $\mathbf{0 . 0 3 3}^{*}$ \\
\hline \multirow{3}{*}{$\begin{array}{l}\text { PMRM with SCGB } \\
\text { PMRM with other infection }\end{array}$} & 18 & $27.7 \%$ & 47 & $72.3 \%$ & 0.222 \\
\hline & 2 & $3.6 \%$ & 53 & $96.4 \%$ & 0.316 \\
\hline & \multicolumn{2}{|c|}{0.008} & \multicolumn{2}{|c|}{0.748} & \\
\hline
\end{tabular}

\section{DISCUSSION}

Premature rupture of membranes presents a serious problem because of their difficult prediction and the mechanisms involved are still unknown. RPM before the term is associated with approximately $50 \%$ of histological chorioamnionitis. Chorioamnionitis have found to be frequency associated with RPM between $15-100 \%$ of the cases of postpartum and postoperative infection (Illia et al., 2018 and Li et al., 2019).
Premature rupture of membranes presented in $30-40 \%$ of preterm births, and is the most common cause of deliveries occurring between 20 weeks and 37 weeks of gestation. In addition, prematurity and low birth weight is leading causes of neonatal death $(31 \%)$ in the world. Determining the most efficacious method to manage PROM in order to minimize its adverse impact on newborns is necessary and paramount to a positive outcome. Infection can be 
associated with PROM as either a cause or a consequence (Zeng et al., 2014).

Preterm premature rupture of membranes is associated with maternal and fetal pathologies, contributing to the birth of premature infants. 3 The longer the time elapsed between rupture and delivery, the greater the chance of infection for both mother and fetus. 4 The most common cause of PPROM is spontaneous, which has a multifactorial etiology. It may be related to a structural defect in the membranes due to collagen deficiency or malformation, to the weakening of the membranes due to enzymatic destruction in inflammatory or infectious processes, and to sac exposure due to isthmus-cervix incompetence (Hackenhaar et al., 2014).

This was a prospective study that conducted on pregnant women suffering from vaginal infection with group B streptococcal infection selected from the Obstetrics and Gynecology Department of Al-Azhar Main University Hospital and Sedi Salem General Hospital.

Our results revealed that the mean age of women 29.19C3.4 years and the gestational age mean was $37.4 \pm 1.7$ weeks.

Lee and his colleagues (2018) found that the age of pregnant women with GBS positive cultures was $32.6 \pm 4.6$ years which were in agreement with our results (Lee et al., 2018).

Khan and his colleagues, reported in their study that GBS colonization occurred in pregnant women $>40$ years o age because ethnicity, obesity, low vitamin D intake, hygiene, sexual activity, health care occupation, and illiteracy have also been associated with GBS vaginal carriage (Khan et al., 2015).

The presence of fever, vaginal pain and discharge were the common presenting symptoms.

Hull and McLellan (2016) reported found that vaginal discharge and painfull vagina were the common presenting symptoms which run in line with our results.

The presence of leukocytosis in CBC, pus cells in urine and the organism in vaginal smear are the common evidence.

Lee and his Colleagues (2018) found that leukocytosis is a mandatory finding in cases of pregnant women with PROM with GBS positive cultures.

Streptococci were the common organism in our series, followed by mixed infection, fugi and the least was staphylococci.

Zeng and Coworkers (2014) found in their studies that Streptococcus infection was the common form of vaginal infection. $W u$ (2011) and Yang with his Colleagues (2012) found that mixed infection was the common form and the least common organism was staphylococci.

Our study revealed that the presence of vaginal infections increases the incidence of PROM and the most common organism causes PROM was thestreptococci group B.

Jassir and his Colleagues (2017) found that GBS reported in $48.4 \%$ of cases of their study which run in lines with our results. 


\section{CONCLUSION}

The presence of vaginal infections in general increases the incidence of premature rupture of membranes especially with group B streptococci which increases the incidence of PROM more.

\section{REFERENCES}

1. Alp F, Findik D, Dagi HT, Arslan U, Pekin AT and Yilmaz SA. (2016): Screening and genotyping of group B Streptococcus in pregnant and nonpregnant women in Turkey. J Infect Dev Ctries., 10(3): 222-6.

2. HackenhaarAA, AlbernazEP, and da Fonseca TMV (2014): Preterm premature rupture of the fetal membranes: association with sociodemographic factors and maternal genitourinary infections.J Pediatr (RioJ)., 90(2):197-202.

3. Hull CE and McLellan AR, (2016): Acute and Recurrent Bacterial Vaginosis. Clinic Rev., 43-48.

4. Illia R, Solana C, and Lobenstein G, (2018): Complications of pregnancy: premature rupture of membranes, chorioamnionitis, amnioinfusion, prenatal administration of surfactanct. Int J Pregn Chi Birth., 4(1): 48-60.

5. Jassir FH, Seale AC, Lynch MK, Lawn JE, Baker CJ, Bartlett L, Cutland C, Gravett MG, Heath PT, Ip M, Le Doare K, Madhi SA, Saha SK, Schrag S, Meulen AS, Vekemans J and Rubens CE. (2017): Preterm Birth Associated with Group B Streptococcus Maternal Colonization Worldwide: Systematic Review and
Meta-analyses. Clin Infect Dis., 65(S2): S133-42.

6. Khan MA, Faiz A, and Ashshi AM. (2015): Maternal colonization of group B Streptococcus: prevalence, associated factors and antimicrobial resistance. Ann Saudi Med., 35(6): 423-7.

7. Kobayashi M, Schrag SJ, Alderson MR, Madhi SA, Baker CJ, Meulen AS, Kaslow DC, Smith PG, Moorthy VS and Vekemans J. (2016): WHO consultation on group B Streptococcus vaccine development: Report from a meeting held on 27-28 April 2016. Vaccine, 16: 390-410.

8. Le Doare $K$ and Heath PT. (2013): An overview of global GBS epidemiology. Vaccine, 31(4): 7-12.

9. Lee YH, Lee YJ, Jung SY, Kim SY, Son DW and Seo IH. (2018): Pregnancy and Neonatal Outcomes of Group B Streptococcus Infection in Preterm Births. Perinatology, 29(4): 147-152.

10. Li YY, and Kong CW, and William WKT, (2019): Pathogens in preterm prelabor rupture of membranes and erythromycin for antibiotic prophylaxis: a retrospective analysis. Hong Kong Med J., 25: 287-94.

11. Mohan S, Fatema N, Osit VC, Al-Abri FM and Al-Shafouri NST. (2018): Maternal and Perinatal Outcomes Following Expectant Management of Preterm Premature Rupture of Membranes Before 25 Weeks of Gestation: A Retrospective Observational Study. J Clin Gynecol Obstet., 7 (1), 13-19. 
12. Nakubulwa S, Kaye DK, Bwanga F, Tumwesigye NM and Mirembe FM. (2015): Genital infections and risk of premature rupture of membranes in Mulago Hospital, Uganda: a case control study. BMC Res Notes, 8: 573-581.

13. Patras KA and Nizet V. (2018): Group B Streptococcal Maternal Colonization and Neonatal Disease: Molecular Mechanisms and Preventative Approaches. Front Pediatr., 6: 27-33.

14. Peltier MR, Drobek CO, Bhat G, Saade G, Fortunato SJ, and Menon R, (2012): Amniotic fluid and maternal race influence responsiveness of fetal membranes to bacteria. $\mathbf{J}$ Reprod Immunol 96(1): 68-78.
15. Wu SL. (2011): Analyze the germ culture of the premature rupture of fetal membranes amniotic fluid and the newborn baby throat swab. Chin J Birth Health Hered., 19: 79-80.

16. Yang N, Liu J, Huang JJ and Wu G. (2012): Etiology of neonatal infection related to premature rupture of membranes. Chin J Gen Pract., 11: 199-201.

17. Zeng LN, Zhang LL, Shi J, Gu LL, Grogan W, Gargano MM and Chen C. (2014): The primary microbial pathogens associated with premature rupture of the membranes in China: A systematic review. Taiwan J Obst Gynecol., 53: 443-451. 


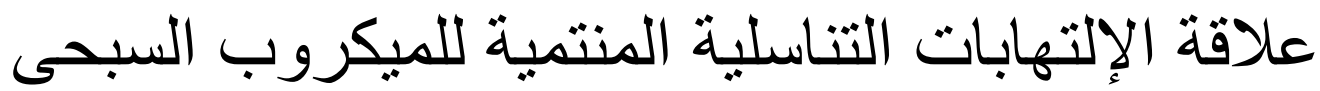

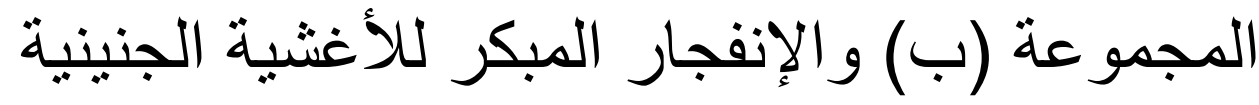

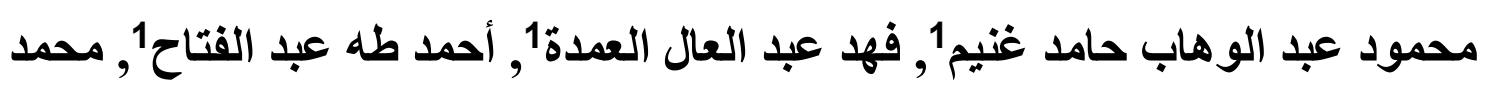
عبد الحمبا خضر 2

قسمي 1التوليا وأمراض النساء، 2الباثولوجيا الإكلينيكية، كلية الطب، جامعة الأزهر

E-mail: $\underline{\text { m-abdelwehab@yahoo.com }}$

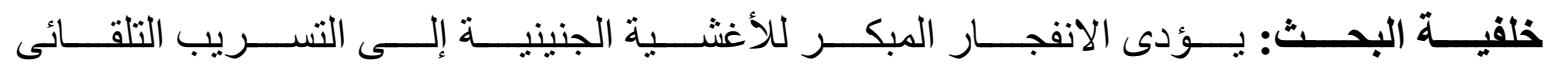

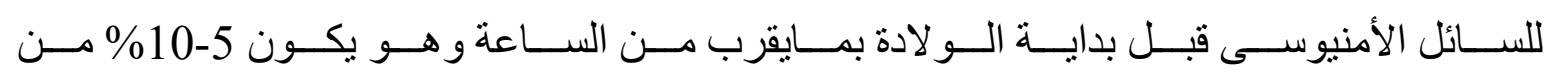

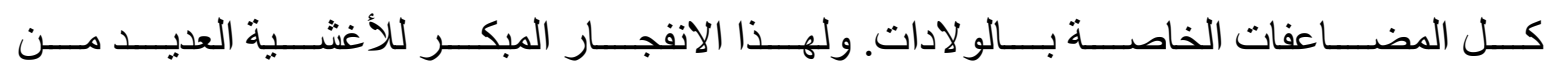

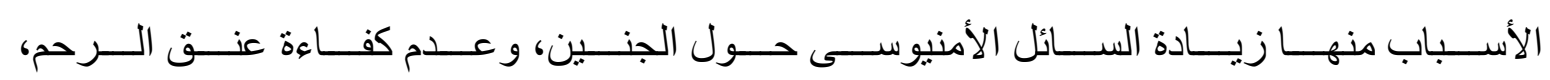

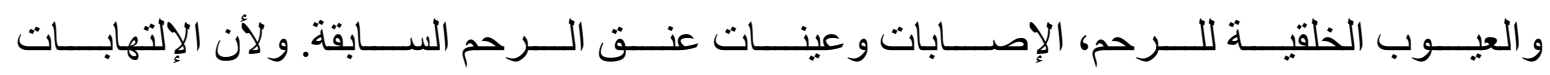

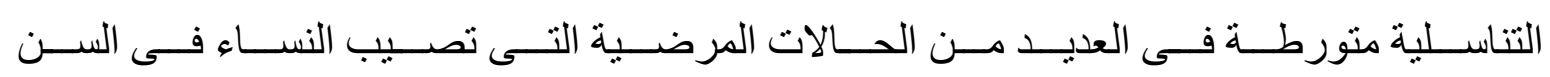
الإنجابية فقد وجد أنها تصاحب الانفجار المبكر للأغشية الجنينية.

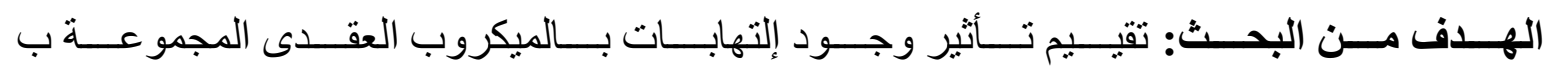

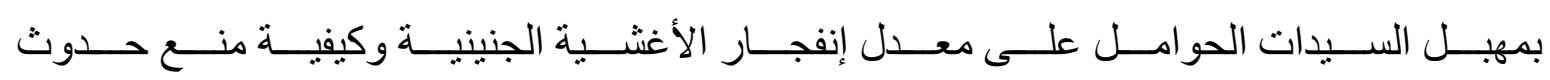

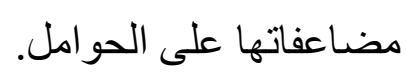

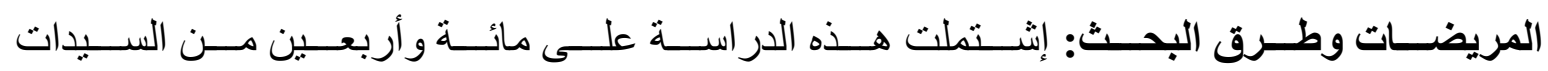

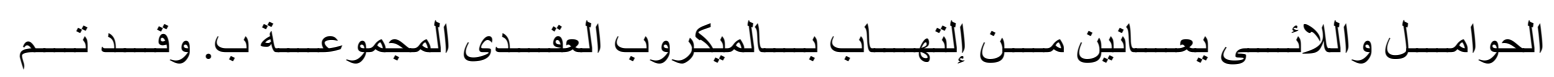

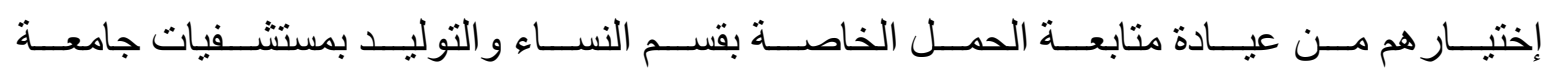

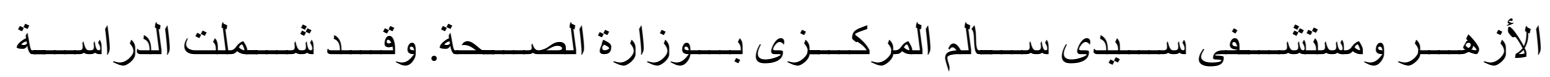

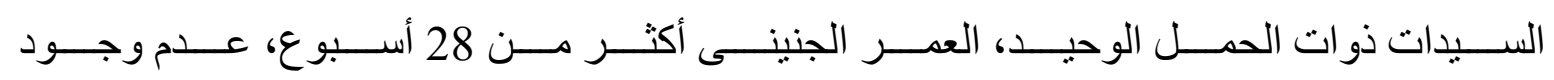

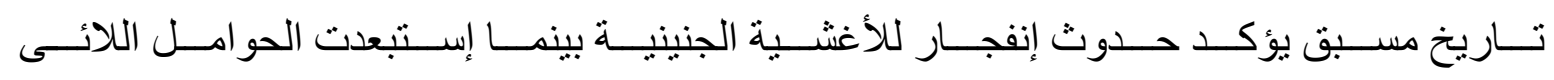

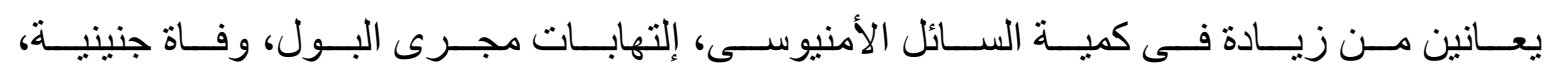
مرض السكرى، العيوب الخلقية الجنينية، الحمل المتعدد و الأورام الليفية للرحم. 


\section{GROUP -B STREPTOCOCCAL GENITAL INFECTION AND...}

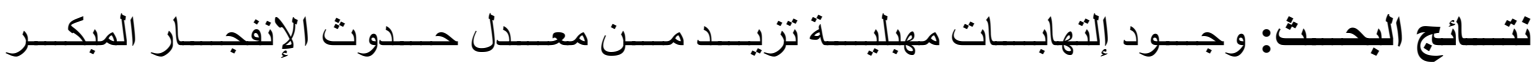

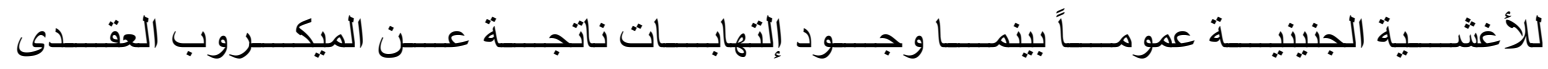
المجمو عة ب تزيد أكثر من حدوث مثل هذه الإنفجار ات للأغثية الجنينية.

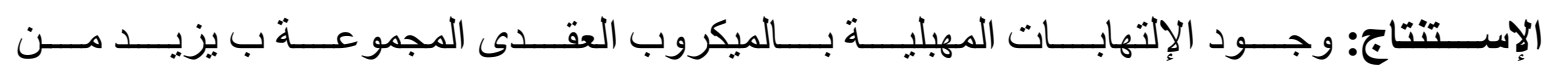
حـدوث الإنفجــار المبكــر للأغشــية الجنينيـــة. العــلاج المبكــر للإلتهابــات يمنــع الإنفجــار المبكر للأغثية الجنينية مع منع حدوث مضاعفاتها.

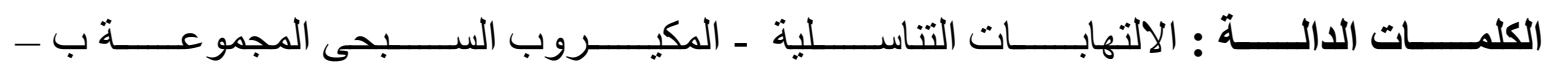
الانفجار للاغشية الجنينية. 